\title{
Non-home prepared foods: contribution to energy and nutrient intake of consumers living in two low-income areas in Nairobi
}

\author{
Hilda van't Riet* ${ }^{*}$ Adel P den Hartog and Wija A van Staveren \\ Division of Human Nutrition and Epidemiology, Wageningen University, PO Box 8129, 6700 EV Wageningen, \\ The Netherlands
}

Submitted 9 March 2001: Accepted 27 November 2001

\begin{abstract}
Objective: To determine the nutritional importance of non-home prepared foods for men, women and schoolchildren living in two low-income residential areas of Nairobi, and the sources of these non-home prepared foods.

Design, setting and subjects: A survey was conducted in Korogocho, a slum area, and Dandora, a low-middle-income residential area. Some 241 men, 254 women and 146 children aged 9 to 14 years were included in the study. Food intake was measured using three 24-hour recalls per individual, with special attention on the sources of all foods consumed.

Results: The median proportion of daily energy intake of consumers provided by nonhome prepared foods ranged from 13\% for schoolchildren in Korogocho to $36 \%$ for men in Dandora. The median contribution to fat intake was higher than to energy, but the contributions to iron and vitamin A intakes were lower than to energy intake. Men consumed more non-home prepared foods on weekdays than at the weekend. Intakes of energy and most nutrients were below Kenyan Recommended Daily Intakes in all groups, but similar for consumers and non-consumers. In Korogocho, street foods were the main source of non-home prepared foods. In Dandora, both kiosks and street foods were major sources.

Conclusions: Non-home prepared foods are an important source of energy and nutients for men, women and schoolchildren in Nairobi. In Korogocho, street foods, and in Dandora, both kiosks and street foods are the main sources of non-home prepared foods. The adequacy of energy and nutrient intakes does not differ between consumers and non-consumers of non-home prepared foods.
\end{abstract}

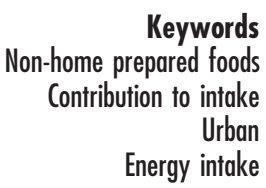

One of the consequences of urbanisation is a change in dietary patterns. In developing countries rural populations consume coarse grains, roots and tubers as main foods, whereas urban populations rely more on wheat and rice and more frequently consume processed foods such as bread, sugar and dairy products ${ }^{1-4}$. Another important phenomenon among urban populations is the tendency to consume more foods outside the house and thus prepare less food at home ${ }^{1-3,5}$.

In this paper we examine the consumption of all foods that have not been prepared at home, regardless of other place at which it is prepared or where it is consumed. Hence, the definition of 'non-home prepared foods' as used in this paper is 'ready-to-eat foods and beverages, processed or fresh, which are acquired outside the consumer's own place of living'.

Street foods are an example of non-home prepared foods that are consumed in urban areas in developing countries (for the definition of street foods, see van't Riet et $a l^{6}{ }^{6}$ ). Large amounts of money circulate in this business $^{7-9}$, indicating the importance of these ready-to- eat foods in the urban diet. Street foods have received ample attention for their role in income generation and hygienic quality ${ }^{9-11}$. Less is known about their contribution to dietary intake. Several studies show that especially the urban poor consume street foods on a regular basis ${ }^{6,12,13}$, because they are cheap and timesaving and can be bought in small quantities ${ }^{6,8}$. According to the Food and Agriculture Organization (FAO) ${ }^{14}$, many urban families would even be worse off without the availability of cheap street foods.

Although street foods supply non-home prepared foods to urban residents, they are not the only source of readyto-eat foods available. Other sources include kiosks (small licensed restaurants) and canteens at work. The types of food sold in kiosks are similar to street foods, but one can buy several of these foods in one kiosk. The same foods are also sold around workplaces, but more choice is available as they also cater for higher-income workers. However, the relevance of these other sources of nonhome prepared foods in the diet of poor urban residents is largely unknown. 
The food intake and nutritional status of poor urban populations are often marginal ${ }^{2}$. The prevalence of stunting in children under five was 33.6\% in Kenya and $30.2 \%$ in Nairobi in 1994. Iron-deficiency anaemia and vitamin A deficiency are certainly thought to be prevalent in Kenya, but the magnitude and distribution of the problems are not clear ${ }^{15}$. Non-home prepared foods might provide an important contribution to the diet of the urban poor.

In Nairobi, many people in low-income areas consume street foods several days per week and the purchase of ready-to-eat foods from kiosks is also common, as has been described previously ${ }^{6}$. Street foods that are consumed most are described by Mwangi et al. ${ }^{16}$. Examples are mandazi (a Kenyan kind of doughnut), samosa (a small meat pie) and potato chips.

Our study aims to answer two questions: (1) Is the consumption of non-home prepared foods of nutritional importance to men, women and schoolchildren living in two low-income residential areas of Nairobi? (2) Are nonhome prepared foods mainly street foods, as the literature suggests, or are more sources available to the urban poor?

\section{Subjects and methods}

\section{Setting and subjects}

A survey was conducted in two previously selected lower- income areas in Nairobi as described before ${ }^{6}$, because the inhabitants belong to the poorer population of Nairobi. Korogocho is a very-low-income slum area and Dandora is a low-middle-income residential area. We randomly selected 302 households out of 1011 households from a previous study, where a cluster of streets in each area was selected and therein all available households were interviewed $^{6}$. From every household we selected a man, and/or a woman and/or a child to assess their food intake, as far as the household contained members fulfilling the criteria. Children were selected in the age range of 9 to 14 years because this is the school-going age and they are old enough to answer some questions themselves.

Initially, 302 households were included, resulting in 669 eligible individuals. The numbers of children, men and women differed (Table 1) because of the selection procedure. The numbers of children are lower than the numbers of adults because one-person households and households without children (in the right age group) were also included in the selection. Eventually, complete food intake records were obtained for 641 individuals from 297 households (149 households from Korogocho and 148 from Dandora).

Enumerators were recruited in the study areas and trained to administer the general questionnaires and 24-hour dietary recalls. Data collection took place between April and July 1999.

Table 1 Characteristics of subjects by study area, separately for consumers and non-consumers* of non-home prepared foods

\begin{tabular}{|c|c|c|c|c|c|}
\hline \multirow[b]{2}{*}{ Group } & \multirow[b]{2}{*}{ Characteristic } & \multicolumn{2}{|c|}{$\begin{array}{l}\text { Korogocho } \\
\text { (slum area) }\end{array}$} & \multicolumn{2}{|c|}{$\begin{array}{c}\text { Dandora } \\
\text { (low-middle-income area) }\end{array}$} \\
\hline & & Consumers & Non-consumers & Consumers & Non-consumers \\
\hline \multirow[t]{9}{*}{ Men } & $n$ & 82 & 30 & 99 & 30 \\
\hline & $\begin{array}{l}\text { Age (years), mean } \pm S D \\
\text { Education }(\%)^{\mathrm{a}}\end{array}$ & $34.9 \pm 9.7$ & $37.5 \pm 11.3$ & $34.2 \pm 7.4$ & $36.3 \pm 9.7$ \\
\hline & None & 22 & 33 & 3 & 10 \\
\hline & Primary school & 42 & 33 & 4 & 17 \\
\hline & Secondary or more & 37 & 33 & 93 & 72 \\
\hline & Employment status (\%) & $\mathrm{b}$ & & & \\
\hline & Unemployed/casual labourer & 45 & 37 & 20 & 23 \\
\hline & Self-employed & 33 & 60 & 22 & 27 \\
\hline & Regularly employed & 22 & 3 & 57 & 50 \\
\hline \multirow[t]{9}{*}{ Women } & $n$ & 94 & 38 & 97 & 25 \\
\hline & $\begin{array}{l}\text { Age (years), mean } \pm \text { SD } \\
\text { Education }(\%) \dagger\end{array}$ & $31.3 \pm 10.2$ & $32.1 \pm 11.2$ & $30.5 \pm 7.0$ & $28.7 \pm 4.3$ \\
\hline & None & 36 & 24 & 8 & 4 \\
\hline & Primary school & 53 & 68 & 20 & 39 \\
\hline & Secondary or more & 11 & 8 & 72 & 57 \\
\hline & Employment status (\%) & & & & \\
\hline & Unemployed/casual labourer & 47 & 45 & 43 & 60 \\
\hline & Self-employed & 51 & 53 & 26 & 28 \\
\hline & Regularly employed & 2 & 3 & 31 & 12 \\
\hline \multirow[t]{2}{*}{ Children } & $n$ & 49 & 19 & 61 & 17 \\
\hline & Age (years), mean \pm SD & $11.2 \pm 1.8$ & $11.2 \pm 1.8$ & $11.1 \pm 1.6$ & $10.4 \pm 1.7$ \\
\hline
\end{tabular}

* Consumers are the individuals in the highest three quartiles of proportion of energy consumed from non-home prepared foods, while the lowest quartile is defined as the non-consumers.

${ }^{\mathrm{b}}$ Difference between consumers and non-consumers, $P<0.05$. 


\section{Food intake assessment}

In three separate visits within several weeks, each subject was interviewed about his/her food intake using 24-hour recalls. During the first visit, data on demographic variables were also collected (including age, educational level and employment status). The dietary recalls covered two weekdays and one weekend day. We recorded all foods consumed from waking up until going to bed, including the amount consumed and source of every single food. For every dish prepared at home all ingredients and amounts were recorded (if necessary with the help of the wife or mother). To facilitate the quantity estimates, standardised household measures (14 cups, plates and bowls in total) were provided by the enumerator and, where possible, the cooking pan used in the house was measured. The enumerators also carried pictures of common fruits and vegetables indicating different sizes. All materials and pictures were based on measured weights, volumes and sizes to estimate portion sizes as accurately as possible. Standardised recipes were used for non-home prepared foods; for each recipe needed, five or six recipes were collected and the average used as the standardised recipe.

\section{Data treatment and analysis}

Nutrient intakes were calculated using the Kenyan food composition table ${ }^{17}$ for $92 \%$ of the products. For three products we used the food composition data from West et $a l .{ }^{18}$, for one product chemical analysis by the department of Food Technology of the University of Nairobi and for three products a release of the Dutch Nutrient Database ${ }^{19}$.

An 'average' day of the week was calculated with the formula: [(weekday $1+$ weekday 2$) \times 2.5+$ weekend day $\times 2] / 7$. The resulting daily intakes have been used for all calculations, except for comparing weekdays and weekends, where the original three intakes were used.

Nutrient adequacies are based on the Kenyan Recommended Daily Intakes (RDIs), age and sex taken into account $^{17}$. For nutrients where a range was given the lower limit was used. Adequacies are presented as percentages of the RDIs.

Differences between the study areas and between men, women and children were tested using Student's $t$-tests or alternatively Mann-Whitney tests for non-normal distributions and chi-square tests for categorical variables. Differences between energy and nutrients were tested with the Wilcoxon signed rank test. Differences between weekdays and weekends were tested with analysis of variance.

Results are presented by study area and by group (men, women and children). A distinction is made between consumers and non-consumers of non-home prepared foods. For comparison within groups, the proportion of participants not consuming any non-home prepared food at all is too small (16\%). Therefore, in this paper, non- consumers are those respondents who form the lowest quartile (of each group) of 'proportion of daily energy consumed as non-home prepared foods'. The highest proportion of energy from non-home prepared foods found among the non-consumers defined this way is $11.5 \%$ for a man from Korogocho (while the overall mean among all non-consumers is $2.2 \%$ ).

\section{Results}

\section{Characteristics of subjects}

Age, education level and employment status of the groups are presented according to study area and consumer status (Table 1). Age did not differ between consumers and nonconsumers in any of the subgroups, nor between the study areas. For the men in the very-low-income area (Korogocho), the consumers had a better employment status than the non-consumers $(P<0.05)$. Men consuming non-home prepared foods in the low-middle-income area (Dandora) had a higher education level than men not consuming them $(P<0.05)$. No differences were found between women consuming or not consuming non-home prepared foods. When comparing the two areas, men and women in Dandora showed a higher education level and employment status than men and women in Korogocho $(P<0.001)$.

\section{Contribution of non-bome prepared food to energy and nutrient intake of consumers}

Table 2 shows the contribution of non-home prepared foods to the daily energy and nutrient intake of men, women and children in the two study areas. The nonconsumers (as defined in the Subjects and methods section) among the men still derive a small part of their daily intake from non-home prepared foods, but among the women and children this amount is negligible. Comparisons are made between consumers only.

Among consumers, the median contribution of nonhome prepared food to the energy intake of men was $27.1 \%$ in Korogocho and 36.2\% in Dandora. For women and children the median proportion ranged between $13 \%$ and 22\% (Table 2).

In both areas, men consumed more of their daily energy and nutrients from non-home prepared foods than women and children $(P<0.01)$ and all groups in Dandora derived more energy and iron from non-home prepared foods than the groups in Korogocho $(P<0.01)$.

The contribution of non-home prepared foods to daily fat intake was higher than the contribution to energy intake in all groups $(P<0.001$; Table 2$)$. Conversely, the contribution of non-home prepared foods to total daily iron intake in Korogocho was lower than to energy intake $(P<0.001)$, while in Dandora the contributions of these foods to vitamin A and calcium were lower than to energy intake $(P<0.001$ and $P<0.05$, respectively). Only for men in Dandora was the proportion of daily iron intake 
Table 2 Proportion (\%) of daily energy and nutrient intakes of men, women and children in Nairobi provided by non-home prepared foods, by study area and non-home prepared consumption level (presented as median proportion (25th-75th percentile))

\begin{tabular}{|c|c|c|c|c|c|}
\hline \multirow[b]{2}{*}{ Group } & \multirow[b]{2}{*}{ Nutrient } & \multicolumn{2}{|c|}{ Korogocho (slum area) } & \multicolumn{2}{|c|}{ Dandora (low-middle-income area) } \\
\hline & & Consumers* & Non-consumers & Consumers & Non-consumers \\
\hline \multirow[t]{7}{*}{ Men } & $n$ & 82 & 30 & 99 & 30 \\
\hline & Energy $^{a}$ & $27.1(18.1-33.9)^{\mathrm{b}, \mathrm{c}}$ & $3.4(0.0-7.5)$ & $36.2(21.9-48.9)^{\mathrm{b}, \mathrm{c}}$ & $6.1(1.6-9.1)$ \\
\hline & Protein & $29.2(19.3-43.2)^{b, c, e}$ & $2.0(0.0-7.1)$ & $34.8(18.8-51.8)^{\mathrm{b}, \mathrm{c}}$ & $3.3(0.0-10.7)$ \\
\hline & Fat & $36.6(25.5-54.9)^{\mathrm{b}, \mathrm{c}, \mathrm{d}}$ & $2.5(0.0-12.6)$ & $42.6(22.3-55.7)^{\mathrm{b}, \mathrm{c}, \mathrm{d}}$ & $5.8(0.0-10.7)$ \\
\hline & Vitamin A & $21.4(10.9-38.4)^{b, c, e}$ & $0.2(0.0-6.8)$ & $17.7(10.3-33.8)^{\mathrm{b}, \mathrm{c}, \mathrm{d}}$ & $1.7(0.0-6.2)$ \\
\hline & $\operatorname{Iron}^{\mathrm{a}}$ & $20.4(8.8-30.3)^{\mathrm{b}, \mathrm{c}, \mathrm{d}}$ & $1.3(0.0-3.4)$ & $54.8(21.5-71.1)^{\mathrm{b}, \mathrm{c}, \mathrm{d}}$ & $3.5(1.3-14.7)$ \\
\hline & Calcium & $25.7(17.5-38.8)^{\mathrm{b}, \mathrm{c}}$ & $2.1(0.0-7.2)$ & $28.6(16.9-47.8)^{\mathrm{b}, \mathrm{c}, \mathrm{e}}$ & $6.2(1.1-8.2)$ \\
\hline \multirow[t]{7}{*}{ Women } & $n$ & 94 & 38 & 97 & 25 \\
\hline & Energy $^{a}$ & $15.4(9.4-23.0)$ & $0.0(0.0-0.1)$ & $20.1(12.2-31.9)$ & $0.0(0.0-3.1)$ \\
\hline & Protein & $15.2(9.1-23.5)$ & $0.0(0.0-0.5)$ & $16.0(8.7-26.9)^{\mathrm{d}}$ & $0.0(0.0-1.6)$ \\
\hline & Fat & $27.1(17.0-35.8)^{d}$ & $0.0(0.0-0.1)$ & $25.1(16.3-41.2)^{d}$ & $0.0(0.0-0.9)$ \\
\hline & Vitamin A & $14.6(7.5-26.5)$ & $0.0(0.0-0.0)$ & $11.4(6.1-23.4)^{d}$ & $0.0(0.0-2.4)$ \\
\hline & $\operatorname{Iron}^{\mathrm{a}}$ & $7.1(3.9-14.5)^{d}$ & $0.0(0.0-0.1)$ & $21.2(6.4-56.0)^{\mathrm{e}}$ & $0.0(0.0-1.9)$ \\
\hline & Calcium & $18.2(10.7-25.0)$ & $0.0(0.0-0.1)$ & $18.5(9.3-26.8)^{\mathrm{e}}$ & $0.0(0.0-2.2)$ \\
\hline \multirow[t]{7}{*}{ Children } & $n$ & 49 & 19 & 61 & 17 \\
\hline & Energy $^{a}$ & $13.4(9.6-20.5)$ & $0.0(0.0-0.0)$ & $22.4(12.9-34.8)$ & $0.0(0.0-0.0)$ \\
\hline & Protein & $14.8(7.5-22.6)$ & $0.0(0.0-0.0)$ & $15.6(8.6-27.8)^{d}$ & $0.0(0.0-0.0)$ \\
\hline & Fat & $26.0(15.7-36.0)^{d}$ & $0.0(0.0-0.0)$ & $26.2(14.6-41.6)^{d}$ & $0.0(0.0-0.0)$ \\
\hline & Vitamin A & $11.7(5.1-21.3)$ & $0.0(0.0-0.0)$ & $14.0(4.9-25.1)^{\mathrm{d}}$ & $0.0(0.0-0.0)$ \\
\hline & Iron $^{a}$ & $8.1(3.6-15.9)^{d}$ & $0.0(0.0-0.0)$ & $17.4(5.7-57.1)$ & $0.0(0.0-0.0)$ \\
\hline & Calcium & $16.1(9.4-27.0)^{\mathrm{e}}$ & $0.0(0.0-0.0)$ & $19.3(11.027 .6)^{\mathrm{e}}$ & $0.0(0.0-0.0)$ \\
\hline
\end{tabular}

aDifference between consumers in Korogocho and Dandora, $P<0.01$.

${ }^{\mathrm{b}}$ Difference between men and women, $P<0.01$.

${ }^{\mathrm{C}}$ Difference between men and children, $P<0.01$

${ }^{\mathrm{d}}$ Different from proportion of daily energy, $P<0.001$

eDifferent from proportion of daily energy, $P<0.05$.

from non-home prepared foods higher than that of daily energy intake $(P<0.001)$.

\section{Weekday or weekend?}

On weekdays a larger proportion of energy intake by men was derived from non-home prepared foods than at weekends. The proportions for consumers in Korogocho were $30.2 \%$ on weekdays versus $21.6 \%$ at the weekend, while in Dandora they were 37.3 vs. $30.2 \%$, respectively $(P<0.05)$. The proportion of fat intake derived from nonhome prepared foods was significantly higher on weekdays than at weekends for men in Dandora ( 41.8 vs. $33.7 \%, P<0.05)$, but not for men in Korogocho. For women and children consuming non-home prepared foods, no differences were found between weekdays and weekends.

\section{Nutritional adequacy}

Total energy intake is low in all groups (Table 3). For all groups energy, protein and fat intakes are higher in Dandora than in Korogocho $(P<0.001$; data not shown). The percentage of energy from fat is $4.5-8 \%$ higher in Dandora than in Korogocho in all groups $(P<0.001)$, while the percentage of energy from protein is around $10 \%$ for all (Table 3).

Within Korogocho, we found no differences between consumers and non-consumers in total energy, protein or fat intake and percentage of energy from protein or fat in any of the groups. In Dandora, children consuming nonhome prepared foods had a lower energy percentage from protein than children who did not consume these foods. Men and women consuming non-home prepared foods in Dandora retrieved a higher energy percentage from fat than the non-consumers $(P<0.05)$. In Korogocho, the higher fat content of the non-home prepared foods facilitated the consumers to reach the same level of fat intake as the non-consumers, while in Dandora this led to a higher energy percentage from fat.

Intakes of energy, protein and vitamin $\mathrm{A}$ are below Kenyan RDIs for all groups (Table 3). Iron intake is adequate, while calcium intake seems adequate for adults but marginal for children. Adequacy of intakes of all nutrients is better in Dandora than in Korogocho in all groups $(P<0.001$; data not shown).

In comparing subjects consuming and not consuming non-home prepared foods, only a few differences in the adequacy of nutrient intakes were observed, which did not point in the same direction. For instance, men consuming non-home prepared foods in Korogocho had a lower vitamin A adequacy than men not consuming these foods; men consuming non-home prepared foods in Dandora had a higher iron adequacy than the men not consuming them; while the children consuming nonhome prepared foods in Dandora had a lower protein adequacy than the children not consuming them. 
Table 3 Energy intake and \% energy from protein and fat (mean \pm standard deviation), and adequacy of energy and nutrients (percentage of RDI presented as median (25th-75th percentile)), according to study area and nonhome prepared consumption level

\begin{tabular}{|c|c|c|c|c|c|}
\hline \multirow[b]{2}{*}{ Group } & \multirow[b]{2}{*}{ Characteristic } & \multicolumn{2}{|c|}{ Korogocho (slum area) } & \multicolumn{2}{|c|}{ Dandora (low-middle-income area) } \\
\hline & & Consumers* & Non-consumers & Consumers & Non-consumers \\
\hline \multirow[t]{9}{*}{ Men } & $n$ & 82 & 30 & 99 & 30 \\
\hline & Energy intake (MJ) ${ }^{\mathrm{a}}$ & $5.6 \pm 1.1$ & $6.3 \pm 2.3$ & $7.1 \pm 1.5$ & $7.1 \pm 2.1$ \\
\hline & Energy $\%$ from protein ${ }^{a}$ & $9.7 \pm 1.7$ & $10.0 \pm 1.7$ & $10.8 \pm 1.8$ & $10.3 \pm 1.6$ \\
\hline & Energy $\%$ from fat ${ }^{a}$ & $19.1 \pm 5.5$ & $18.4 \pm 6.0$ & $27.0 \pm 5.3^{\mathrm{b}}$ & $23.8 \pm 7.8$ \\
\hline & $\begin{array}{l}\text { Adequacy (\% of RDI) } \\
\text { Enerav }^{\mathrm{a}} \text { ( }\end{array}$ & & & & \\
\hline & Protein $^{a}$ & $\begin{array}{l}52(46-58) \\
65(53-74)\end{array}$ & $\begin{array}{l}5 b(44-10) \\
68(57-86)\end{array}$ & $\begin{array}{l}64(5 /-16) \\
87(75-105)\end{array}$ & $\begin{array}{l}64(55-74) \\
82(70-100)\end{array}$ \\
\hline & Vitamin $A^{a}$ & $27(21-43)^{b}$ & $40(33-66)$ & $56(40-75)$ & $55(46-77)$ \\
\hline & $\operatorname{Iron}^{\mathrm{a}}$ & $406(334-499)$ & $416(311-526)$ & $737(436-1145)^{b}$ & $517(426-774)$ \\
\hline & Calcium & $160(112-199)$ & $180(119-217)$ & $187(149-232)$ & $175(141-208)$ \\
\hline \multirow[t]{9}{*}{ Women } & $n$ & 94 & 38 & 97 & 25 \\
\hline & Energy intake $(\mathrm{MJ})^{\mathrm{a}}$ & $5.1 \pm 0.9$ & $5.2 \pm 1.7$ & $6.7 \pm 1.9$ & $6.5 \pm 1.9$ \\
\hline & Energy \% from protein & $9.6 \pm 1.7$ & $10.1 \pm 1.9$ & $9.7 \pm 1.5$ & $10.2 \pm 1.4$ \\
\hline & Energy $\%$ from fat ${ }^{a}$ & $18.3 \pm 5.7$ & $16.9 \pm 6.2$ & $24.6 \pm 6.2^{b}$ & $21.4 \pm 5.6$ \\
\hline & Energy ${ }^{a}$ & $61(51-68)$ & $61(47-68)$ & $77(62-92)$ & $71(60-90)$ \\
\hline & Protein ${ }^{\mathrm{a}}$ & $65(57-85)$ & $70(56-87)$ & $92(72-111)$ & $86(74-109)$ \\
\hline & Vitamin $A^{a}$ & $34(22-46)$ & $36(24-49)$ & $60(43-79)$ & $64(48-87)$ \\
\hline & Iron $^{\mathrm{a}}$ & $124(110-161)$ & $118(97-169)$ & $207(151-305)$ & $174(144-241)$ \\
\hline & Calcium $^{\mathrm{a}}$ & $136(103-183)$ & $134(89-169)$ & $167(136-206)$ & $170(139-211)$ \\
\hline \multirow[t]{9}{*}{ Children } & $n$ & 49 & 19 & 61 & 17 \\
\hline & Energy intake $(\mathrm{MJ})^{\mathrm{a}}$ & $4.0 \pm 0.9$ & $3.6 \pm 1.3$ & $5.8 \pm 1.5$ & $5.6 \pm 1.5$ \\
\hline & Energy \% from protein & $10.3 \pm 3.5$ & $10.6 \pm 1.4$ & $9.3 \pm 1.3^{\mathrm{b}}$ & $11.0 \pm 1.2$ \\
\hline & Energy \% from fat ${ }^{\mathrm{a}}$ & $16.5 \pm 4.7$ & $16.1 \pm 5.5$ & $23.8 \pm 6.3$ & $21.0 \pm 6.3$ \\
\hline & Energy $^{\mathrm{a}}$ & $42(38-49)$ & $39(34-45)$ & $62(54-73)$ & $64(54-76)$ \\
\hline & Protein ${ }^{a}$ & $59(48-74)$ & $58(55-66)$ & $82(72-97)^{\mathrm{b}}$ & $108(98-122)$ \\
\hline & Vitamin $A^{a}$ & $33(22-45)$ & $28(18-45)$ & $69(49-83)$ & $81(62-115)$ \\
\hline & $\operatorname{Iron}^{\mathrm{a}}$ & $194(162-255)$ & $201(142-224)$ & $376(284-652)$ & $327(260-357)$ \\
\hline & Calcium $^{\mathrm{a}}$ & $79(53-90)$ & $66(46-71)$ & $95(84-129)$ & $98(89-140)$ \\
\hline
\end{tabular}

${ }^{*}$ Consumers are the individuals in the highest three quartiles of proportion of energy consumed from non-home prepared foods, while the lowest quartile is defined as the non-consumers.

a Difference between Korogocho and Dandora, $P<0.001$.

${ }^{\mathrm{b}}$ Difference between consumers and non-consumers within the area, $P<0.05$.

Table 4 Proportion (\%) of energy in the daily meals (presented as median (25th-75th percentile)) provided by non-home prepared foods according to study area and group, for consumers only

\begin{tabular}{|c|c|c|c|c|c|}
\hline \multirow[b]{2}{*}{ Group } & \multirow[b]{2}{*}{ Meal type } & \multicolumn{2}{|r|}{$\begin{array}{l}\text { Korogocho } \\
\text { (slum area) }\end{array}$} & \multicolumn{2}{|r|}{$\begin{array}{c}\text { Dandora } \\
\text { (low-middle- } \\
\text { income area) }\end{array}$} \\
\hline & & $n$ & $\%$ & $n$ & $\%$ \\
\hline Men & $\begin{array}{l}\text { Breakfast }^{\mathrm{a}} \\
\text { Lunch }^{\mathrm{a}} \\
\text { Dinner } \\
\text { Snacks }\end{array}$ & 82 & $\begin{array}{l}35(12-46) \\
51(35-75)^{\mathrm{cd}} \\
0(0-0) \\
0(0-0)\end{array}$ & 99 & $\begin{array}{l}21(0-40) \\
72(48-100)^{\mathrm{cd}} \\
0(0-0) \\
43(0-100)\end{array}$ \\
\hline Women & $\begin{array}{l}\text { Breakfast }^{\mathrm{a}} \\
\text { Lunch }^{\mathrm{a}} \\
\text { Dinner } \\
\text { Snacks }^{\mathrm{a}}\end{array}$ & 94 & $\begin{array}{l}30(19-41) \\
0(0-31) \\
0(0-0) \\
0(0-0)\end{array}$ & 97 & $\begin{array}{l}21(0-37) \\
29(0-56) \\
0(0-0) \\
33(0-79)\end{array}$ \\
\hline Children & $\begin{array}{l}\text { Breakfast } \\
\text { Lunch }^{b} \\
\text { Dinner } \\
\text { Snacks }^{a}\end{array}$ & 49 & $\begin{array}{l}23(5-42) \\
0(0-34) \\
0(0-0) \\
0(0-0)\end{array}$ & 61 & $\begin{array}{l}27(0-40) \\
26(0-51) \\
0(0-0) \\
64(28-95)\end{array}$ \\
\hline
\end{tabular}

a Difference between Korogocho and Dandora, $P<0.01$.

${ }^{\mathrm{b}}$ Difference between Korogocho and Dandora, $P<0.05$

${ }^{c}$ Difference between men and women, $P<0.001$.

${ }^{\mathrm{d}}$ Difference between men and children, $P<0.001$
Non-home prepared foods as part of the daily meals In the slum area of Korogocho, breakfast provided 38\% of daily energy, lunch $29 \%$, dinner $32 \%$ and snacks $1 \%$. In Dandora, the low-middle-income area, the division was breakfast $31 \%$, lunch $30 \%$, dinner $31 \%$ and snacks $8 \%$. These percentages were similar for men, women and children,

For all groups of consumers, non-home prepared foods contributed importantly to energy in breakfast (ranging from 21 to $35 \%$ ) and for men even more during lunch (5172\%) (Table 4). Men in Korogocho derived a larger proportion of breakfast energy from non-home prepared foods than men in Dandora $(P<0.01)$, while all groups in Dandora derived a larger proportion of energy from nonhome prepared foods during lunch and snacks $(P<0.05)$. In both areas men derived more energy from non-home prepared foods for lunch than women and children $(P<$ 0.001). Non-home prepared foods played a minor role at dinnertime in both areas.

Non-home prepared foods are usually consumed as a replacement for home-prepared foods, but not necessarily as a replacement for the whole meal (data not shown). 
When taken for breakfast, non-home prepared foods mostly form the solid component, consumed in combination with home-prepared tea (with sugar and often milk as well). Non-home prepared lunch is usually a complete replacement of a home-prepared lunch, because the consumer is a long distance away from home. More than 95\% of all dinners are fully home-prepared, and in the other cases one component (e.g. fried fish) is added to an otherwise home-prepared dinner. The place of preparation of snacks simply varies with the place and time of consumption.

\section{Sources of non-bome prepared foods}

In the slum area, Korogocho, street foods were the main source of non-home prepared energy for men, women and children (Fig. 1). For men, the place of work and kiosks also played a role, while foods eaten at school provided part of the energy for the children.

In the low-middle-income area, Dandora, kiosks were the main non-home prepared food source for men and women (Fig. 1), while street foods were a major source as well. Conversely, street foods were the main source for the children, with kiosks forming an important second source. Work and school were less important sources.

Other sources - i.e. foods eaten at the house of a friend or relative and gifts - played only a minor role in Korogocho. In Dandora, these other sources contributed $15 \%$ of daily energy for the women and $17 \%$ of daily energy for the children.

\section{Discussion}

This study shows that non-home prepared foods are an important source of energy and nutrients for men, women and schoolchildren from a slum area and a low-middleincome area in Nairobi. Street foods were the main source of non-home prepared foods in the slum area, while kiosk foods were the main source in the low-middle-income area.

In this study we used 24-hour recalls to assess dietary intake. At group level, repeated 24-hour recalls can provide a proper estimate of dietary intake ${ }^{20,21}$. A major advantage of the 24-hour recall method was the possibility to easily record the sources of the consumed non-home prepared foods.

The results of this study show a low food intake and low adequacy for most nutrients. As the study took place in low-income areas this is not an unexpected finding, but it might be aggravated by the reported tendency of 24-hour recalls to underestimate food intake ${ }^{22,23}$. Although we expected differences between the areas, part of this might also be explained by the difference in education level. The lower education level of the study population in Korogocho (slum area) might cause a lower ability to recall the type and quantities of the products they consumed.

Although seasonality has much less influence in urban than in rural areas, it may cause a bias as the types and prices of foods vary during the year. As our data were collected within a few weeks in one season, seasonality has not been taken into account. This means that the contributions of non-home prepared foods to the daily intakes of specific nutrients vary in magnitude in other seasons; however, this does not change the implications of our findings.

The contribution of non-home prepared foods to energy intake of consumers ranged from a median of $13 \%$ to $36 \%$ for subjects living in low-income areas in
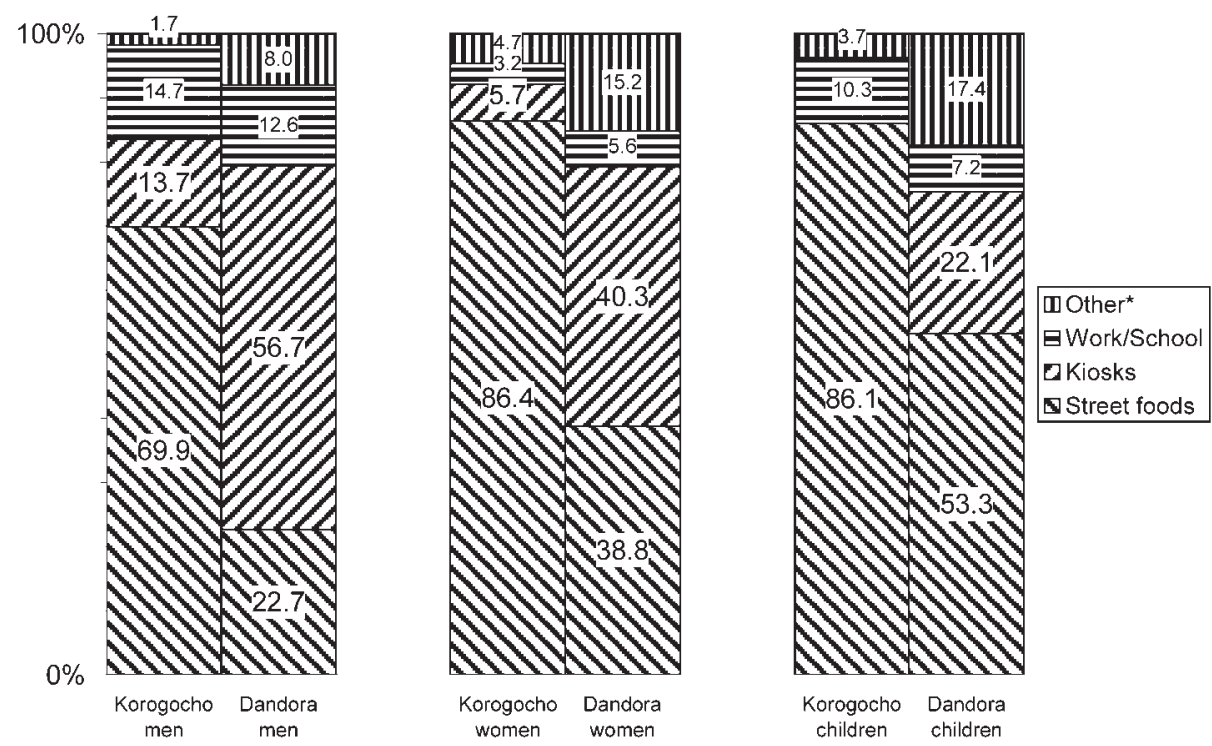

Fig. 1 Mean proportion (\%) of the contribution of different sources to the energy derived from non-home prepared foods, for men, women and children in two low-income areas in Nairobi by study area. "Consumed at the house of a friend or relative and gifts 
Nairobi. Male urban workers from a slum in Hyderabad, India $^{24}$, both male and female students in Nigeria ${ }^{25}$ and Haitian schoolchildren ${ }^{26}$ consume comparable proportions of their diet from non-home prepared foods. Oguntona and Tella ${ }^{27}$ found that even $59 \%$ of daily energy came from street foods in Nigerian market women. Because they spend their whole day at the market, they depend on the foods being sold around. Combined, these results indicate the importance of non-home prepared foods in the diet of poor urban residents, whose energy and nutrient intakes are usually low.

Non-home prepared foods contributed more to the diet of men than to the diets of women and children in this study. This is because most men eat their lunch away from home, as their place of work is too far away to return home during the lunch break. This also explains the difference between weekdays and weekends. In a study by $\mathrm{Ag}$ Bendech et al. ${ }^{13}$, street foods supplied a larger part of the recommended energy and nutrients for children than for adults in low-income families in Bamako (Mali). This can be explained by the fact that most men in their study (85.3\%) consume their lunch at home, which appears possible in the less urbanised Bamako area but is hard in the large city of Nairobi.

In none of the groups did the daily diet provide an adequate supply of all nutrients. Energy, protein and vitamin A intakes were below RDIs for all groups. Calcium intake appeared to be marginal to adequate, while only iron intake was found to be adequate. However, the iron consumed mainly originates from vegetable products, resulting in low bioavailability ${ }^{28}$. In addition, the adequacy is based on the bottom of the range of RDI, which means that only minimal safety margins are included; thus the adequacy of the actual absorption is unknown.

The types of food derived from non-home prepared sources differ from home-prepared foods. The proportion of fat intake contributed by non-home prepared foods is higher than that of energy and protein, indicating that nonhome prepared foods have a higher fat content. Mandazi (a kind of doughnut) is an example of a frequently consumed non-home prepared food with a high fat content and reasonable price. It is usually not prepared at home because it takes a long time to prepare. This makes street-food mandazi a convenient and tasty fat-rich breakfast or snack that can improve the food intake of poor urban inhabitants, as their energy intake is below the RDI.

The contribution of non-home prepared foods to the intake of micronutrients was lower than the contribution to energy intake, indicating a low nutrient density of the non-home prepared foods. However, the energy and nutrient adequacy is the same for consumers and nonconsumers, suggesting that the types of products consumed as non-home prepared foods are not very different from the foods that are consumed at home by non-consumers.
Licensed kiosks were the main source of non-home prepared foods in the higher-income area of Dandora, while informal street foods were the main source in the slum area of Korogocho. This is a clear indication that the process of preparing less food at the household level is taking place at different levels in the urban society. Time pressure is increasing for all urban residents, leading to the purchase of non-home prepared foods. Street food is an important part of this phenomenon, but even for the poor is not the only component, as other sources of non-home prepared foods are also available. Yet, the poorest prefer street foods because they are cheap and can be bought in small quantities, while kiosk foods are consumed by the slightly less poor who can afford to do so.

In conclusion, the adequacy of energy and nutrient intakes does not differ between consumers and nonconsumers of non-home prepared foods. Apparently consumption of non-home prepared foods does not lead to a higher nutritional quality of the diet, but it does not have a negative impact either. A higher nutritional quality was found only in the higher fat and iron intakes by men from Dandora consuming non-home prepared foods as compared with non-consumers. Moreover, for the urban poor, consumption of non-home prepared foods is a worthwhile strategy to utilise: apart from providing a similar nutritional adequacy to that of non-consumers, non-home prepared foods have the advantages of saving time and being relatively cheap, as usually small quantities are bought at a time.

\section{Acknowledgements}

We wish to thank Provide International in Korogocho and the Gospel Tabernacle Church in Dandora for providing us with offices in the field and attaching their name to our project, enabling us to obtain the confidence of many participants. We gratefully acknowledge the financial support from the Netherlands Foundation for the Advancement of Tropical Research (WOTRO), grant number WV 96-153.

\section{References}

1 Popkin BM, Bisgrove EZ. Urbanization and nutrition in lowincome countries. Food Nutr. Bull. 1988; 10: 3-23.

2 von Braun J, McComb J, Fred-Mensah BK, Pandya-Lorch R. Urban Food Insecurity and Malnutrition in Developing Countries: Trends, Policies, and Research Implications. Washington, DC: International Food Policy Research Institute, 1993.

3 Drewnowski A, Popkin BM. The nutrition transition: new trends in the global diet. Nutr. Rev. 1997; 55: 31-43.

4 Kennedy E, Reardon T. Shift to non-traditional grains in the diets of East and West Africa: role of women's opportunity cost of time. Food Policy 1994; 19: 45-56.

5 Delisle H. Les styles alimentaires urbains. Food Nutr. Agric. 1991; 1: 7-10

6 van't Riet $H$, den Hartog AP, Mwangi AM, Mwadime RKN, Foeken DWJ, van Staveren WA. The role of street foods in 
the dietary pattern of two low-income groups in Nairobi. Eur. J. Clin. Nutr. 2001; 55: 562-70.

7 Dawson RJ, Canet C. International activities in street foods. Food Control 1991; 2: 135-9.

8 Winarno FG, Allain A. Street foods in developing countries: lessons from Asia. Food Nutr. Agric. 1991; 1: 11-8.

9 Food and Agriculture Organization (FAO). Street Foods. FAO Food and Nutrition Paper 63. Rome: FAO, 1997.

10 Tinker I. Street Foods: Urban Food and Employment in Developing Countries. New York: Oxford University Press, 1997.

11 Ekanem EO. The street food trade in Africa: safety and socioenvironmental issues. Food Control 1998; 9: 211-5.

12 Atuanya EI. Nutrition as an indicator of urban poverty. A dietary survey of the urban poor in Benin City, Nigeria. In: Makinwa PK, Ozo AO, eds. The Urban Poor in Nigeria. Benin: Evans Brothers, 1987; 109-27.

13 Ag Bendech M, Chauliac M, Malvy DJM. Assessment of dietary intake at home and outside the home in Bamako (Mali). Ecol. Food Nutr. 1998; 37: 135-62.

14 Food and Agriculture Organization (FAO). Street Foods. FAO Food and Nutrition Paper 46. Rome: FAO, 1990.

15 Government of Kenya/UNICEF. Situation Analysis of Children and Women in Kenya 1998. Nairobi: United Nations Office at Nairobi, 1998.

16 Mwangi AM, den Hartog AP, Foeken DWJ, van't Riet H, Mwadime RKN, van Staveren WA. The ecology of street foods in Nairobi. Ecol. Food Nutr. 2001; 40: 497-523.

17 Sehmi JK. National Food Composition Tables and the Planning of Satisfactory Diets in Kenya. Nairobi: Ministry of Health/National Public Health Laboratory Services, 1993.

18 West CE, Pepping F, Temalilwa CR. The Composition of Foods Commonly Eaten in East Africa. Wageningen: Wageningen Agricultural University for CTA and ECSA, 1988.

19 NEVO. Nederlands Voedingsstoffenbestand 1993. Den Haag:
Voorlichtingsbureau voor de Voeding/Stichting Nederlands Voedingsstoffenbestand, 1993.

20 Gibson RS. Principles of Nutritional Assessment. New York: Oxford University Press, 1990.

21 Sawaya AL, Tucker K, Tsay R, Willett W, Saltzman E, Dallal GE, Roberts SB. Evaluation of four methods for determining energy intake in young and older women: comparison with doubly labeled water measurements of total energy expenditure. Am. J. Clin. Nutr. 1996; 63: 491-9.

22 Bathalon GP, Tucker KL, Hays NP, Vinken AG, Greenberg AS, McCrory MA, Roberts SB. Psychological measures of eating behavior and the accuracy of 3 common dietary assessment methods in healthy postmenopausal women. Am.J. Clin. Nutr. 2000; 71: 739-45.

23 Kroke A, Klipstein-Grobusch K, Voss S, Möseneder J, Thielecke F, Noack R, Boeing H. Validation of a selfadministered food-frequency questionnaire administered in the European Prospective Investigation into Cancer and Nutrition (EPIC) study: comparison of energy, protein, and macronutrient intakes estimated with the doubly labeled water, urinary nitrogen, and repeated 24-h dietary recall methods. Am. J. Clin. Nutr. 1999; 70: 439-47.

24 Sujatha T, Veena S, Narasimha RG, Krishna RG, Padmavathi KS, Vidyasagar P. Street food: an important source of energy for the urban worker. Food Nutr. Bull. 1997; 18: 318-22.

25 Oguntona CRB, Kanye O. Contribution of street foods to nutrient intakes by Nigerian adolescents. Nutr. Health 1995; 10: $165-71$.

26 Webb RE, Hyatt SA. Haitian street foods and their nutritional contribution to dietary intake. Ecol. Food Nutr. 1988; 21: 199-209.

27 Oguntona CRB, Tella TO. Street foods and dietary intakes of Nigerian urban market women. Int. J. Food Sci. Nutr. 1999; 35: $262-7$.

28 Hurrell RF. Bioavailability of iron. Eur.J. Clin. Nutr. 1997; 51 : S4-8. 